\title{
Effects of age and parity on the breeding potential of mice with one or two ovaries
}

\author{
R. G. Gosden* \\ Physiological Laboratory, University of Cambridge, and Department of Physiology, University \\ of Edinburgh, U.K.
}

\begin{abstract}
Summary. Although removal of one ovary from young CBA/Ca mice and CFLP mice did not reduce the overall numbers of ova shed at ovulation, the total number of live offspring delivered during the lifespan was reduced to $65 \%$ and $50 \%$, respectively, of control values. This reduction was due to fewer and smaller litters. The capacity of intact and unilaterally ovariectomized animals to support gestation of embryos transferred from young donors was tested to determine whether premature exhaustion of uterine function had occurred as a result of embryo overloading. An effect of breeding history on embryo survival to Day 19 of pregnancy was found after unilateral transfer, the least favourable sites for survival being the primigravid horns of ageing intact and unilaterally ovariectomized mice $(0 \%$ and $1 \%$ survival, respectively, in $\mathrm{CBA} / \mathrm{Ca}$ mice). The proportion of embryos surviving in multiparous horns of the one-ovary animals $(24 \%)$ was greater than in horns of primigravidae and less than in horns of intact multigravidae of similar age and parity (48\%). A larger proportion of ova survived in young uteri than in any of these aged horns. The results suggested that the normal decline with age in breeding potential is due to decreased uterine capacity and that the rate of loss is accelerated by both repeated embryo overloading and prolonged nulliparity, probably as a result of local factors. The decidual response was reduced in older animals, although there was no clear-cut variation with parity. Ageing uteri accumulated mast cells and macrophages, but the latter were abundant only in multiparous horns and were probably related to puerperal involutionary activities. There was no evidence that these changes in cell number or response were responsible for decreased gestational potential in ageing animals.
\end{abstract}

\section{Introduction}

Removal of one ovary from young polytocous laboratory rodents leads to a prompt compensation in numbers of ova shed at oestrus by the remaining ovary (McLaren, 1966). Such ova may be fertilized normally, although they implant only in the uterine horn ipsilateral to the remaining ovary because internal migration of ova is rare or anatomically impossible in these species.

Long-term studies of the effects of unilateral ovariectomy on fertility in rabbits and rodents have shown that when one ovary was removed in early maturity the single functioning uterine horn was initially able to carry the additional feto-placental load to term. However, the subsequent litters were reduced in size as the incidence of intrauterine mortality increased. U.K.

* Present address: Department of Physiology, University Medical School, Teviot Place, Edinburgh EH8 9AG. 
Animals with a single ovary produced only about half as many offspring in toto during the breeding life-span as intact controls (Jones \& Krohn, 1960; Biggers, Finn \& McLaren, 1962a; Blaha, 1964; Adams, 1970). These results could not be explained by premature ovarian failure in animals with one ovary (Biggers, Finn, McLaren \& Woolf, 1962b). The possibility, therefore, that the uterus can only support a limited number of implantations during life and that the breeding potential of such species may be limited primarily by uterine factors raises several interesting questions: (1) does repeated embryo overloading of the uterus mainly affect the quality of the uterine environment and, if so, is this due to an acceleration of the normal ageing process; (2) what is the functional potential of the barren horn in multiparous unilaterally ovariectomized mice; and (3) what, if any, structural changes occur in relation to changes in functional capacity of the uterus? The present study was an attempt to answer these questions by testing the uterine response of mice to a challenge by embryos or artificial stimuli.

\section{Materials and Methods}

Outbred CFLP and inbred CBA/Ca female mice were obtained at 4 weeks of age from commercial sources. They were maintained in temperature-controlled $\left(23 \pm 1^{\circ} \mathrm{C}\right)$ and artifically lit rooms (14 h light/day) and were provided with food pellets and water ad libitum. Standard randomization methods were used for allocating animals to their treatment groups and for selecting the side for unilateral surgery. Surgical anaesthesia was induced with tribromoethanol (Avertin: Winthrop, Surbiton-upon-Thames, U.K.).

\section{Long-term ovarian function}

The ovarian cycle was studied in 54 virgin $\mathrm{CBA} / \mathrm{Ca}$ mice between 6 and 30 weeks of age. One ovary was removed from 32 animals at 6 weeks of age, the other animals were used as sham-operated controls. Since groups of female mice tend to become acyclic in the absence of male odour, a foreign male mouse (C57BL $\times \mathrm{A}_{2} \mathrm{G}$ ) was kept in perforated enclosure attached to the roof of the females' cage. Oestrous cycle lengths were determined by examination of daily vaginal smears. The mice were killed by cervical dislocation at the first or second oestrus after surgery or at oestrus when $12,18,24$ or 30 weeks old. The ovulation number was estimated by counting freshly ovulated ova in oviduct flushings.

\section{Breeding experiments}

Pairs of female mice were each housed with a proven fertile male of the same strain. The young were removed and counted within $24 \mathrm{~h}$ of parturition to avoid the suckling-induced prolongation of pregnancy after re-impregnation at the post-partum oestrus, thus providing the maximum number of opportunities for conception during life. Some of the female mice had been unilaterally ovariectomized a few days before introducing them to their mates; others were shamoperated. All female mice were killed and autopsied 12 weeks after the birth of the last litter, when they were considered to be sterile. Sickly animals and those with substantial pathological lesions were excluded from the study. Stud males were replaced if sub-fertility was suspected on the grounds of unexpectedly reduced breeding performance of both of the female mice.

$\mathrm{CBA} / \mathrm{Ca}$ mice in an additional group were maintained as virgins until they were 32-40 weeks old when multiparae of the same strain were becoming sterile. The breeding potential of this group was then tested by pairing with males of the same strain.

The products of the first conception in 14 young intact and 13 young unilaterally ovariectomized $\mathrm{CBA} / \mathrm{Ca}$ mice were studied at autopsy on Day 19 (Day $1=$ day of coital plug). The numbers of hyperaemic CL and live and resorbing fetuses were counted. Fetuses and their 
placentae were weighed and the total fetal protein of the litter was measured (Lowry, Rosebrough, Farr \& Randall, 1951).

\section{Embryo transfer}

Morulae and blastocysts were obtained by flushing the uteri of young CFLP mice on Day 4 post coitum. The animals had previously been induced to superovulate with 5 i.u. PMSG and 5 i.u. hCG (Folligon and Chorulon: Intervet, Bar Hill, Cambridge, U.K.) and mated with CFLP males. Collection and transfer of embryos was carried out with a phosphate-buffered medium containing $0.33 \mathrm{~mm}$-sodium pyruvate, $5.56 \mathrm{~mm}$-glucose and $3 \mathrm{mg} \mathrm{BSA} / \mathrm{ml}$ (Whittingham, 1971).

Pseudopregnancy was established in the recipient animals by mating with vasectomized males ( $\mathrm{C} 57 \mathrm{BL} \times \mathrm{A}_{2} \mathrm{G}$ ) and the embryos were transferred surgically to the uteri on Day 3 of pseudopregnancy. The transfers were unilateral or bilateral but the total number of embryos transferred to each female approximated to the average number of hyperaemic CL in the host group. The recipient animals differed in age, strain, reproductive history and presence of one or both ovaries (see 'Results'). Young recipients were nulliparous and 8-12 weeks old at the time of pairing. Old recipients were approximately 25 weeks old and were either multiparous (3-6 litters) (see previous section for details of husbandry) or had been maintained repeatedly pseudopregnant by pairing with sterile males. Both age and parity were closely matched for comparing the fertility of the various groups of old animals.

At autopsy on Day 19, the numbers of live and resorbing fetuses were recorded. The absence of eye pigment in surviving fetuses showed that they were derived from the transferred embryos. The numbers of CL were counted to provide an estimate of the ovulation number in breeding females.

\section{Decidual cell reaction}

The uterine response to an artificial decidualizing stimulus was studied in groups of $\mathrm{CBA} / \mathrm{Ca}$ and CFLP mice maintained under similar conditions to those described above. The protocol followed that of Finn (1966). The animals were bilaterally ovariectomized and primed sequentially with oestradiol- $17 \beta$ benzoate $(0.2 \mu \mathrm{g} / 100 \mathrm{~g}$ body wt) and progesterone $(2 \mathrm{mg} / 100$ g) (Koch-Light, Colnbrook, U.K.) injected s.c. in arachis oil. An injection of 'nidatory' oestradiol $(0.05 \mu \mathrm{g} / 100 \mathrm{~g})$ was also given. The mice were anaesthetized and the decidual stimulus was provided by transversely crushing one uterine horn in three places with a haemostat. This traumatic stimulus was chosen when strictly unilateral effects on the uterus could not be obtained by intraluminal instillation of arachis oil $(0.02 \mathrm{ml})$. The uteri were dissected at autopsy and each horn was weighed separately. The number of macroscopically visible decidual swellings was noted.

\section{Statistics}

The results were assessed by analysis of variance and by the $\chi^{2}$ test (employing Yates' correction when appropriate).

\section{Microscopical studies}

Small pieces of uterine tissue were collected at autopsy from non-pregnant animals retired from the breeding experiments. Some additional material was collected from primiparous animals during the week following parturition. The tissues were fixed in Susa, 10\% neutral-buffered formalin or formol-calcium fixative. Formalin-fixed frozen sections at 10-16 $\mu \mathrm{m}$ thickness were mounted for u.v. fluorescence microscopy and hydrolytic enzyme histochemistry (acid 
phosphatase (Burstone's method), $\beta$-glucuronidase and non-specific esterase). Paraffin-wax sections $(6-8 \mu \mathrm{m})$ were studied by the following histochemical methods: Perl's method and haematoxylin-Lake method for iron; long Ziehl-Neelsen, Schmorl's ferricyanide and Nile Blue sulphate for lipofuscin granules; Sudan black B for lipids; periodic acid-Schiff reaction (with and without diastase digestion) for lipofuscin granules and carbohydrate. The methods are described by Pearse $(1968,1972)$. Other 6- $\mu \mathrm{m}$ sections were stained with Gomori's paraldehyde fuchsin to demonstrate mast cells: each slide was coded before estimating the number of these cells in 6 randomly chosen areas of $8.4 \times 10^{4} \mu \mathrm{m}^{2}$ of endo- or myometrium in each uterine horn.

Thin slices of tissue were prepared for ultrastructural studies. They were fixed by immersion in $4 \%$ glutaraldehyde in $0.1 \mathrm{~m}$-sodium cacodylate buffer $(\mathrm{pH} 7.2)$ for $1 \mathrm{~h}$ followed by $1 \%$ osmium tetroxide in $0.1 \mathrm{M}$-s-collidine buffer $(\mathrm{pH} \mathrm{7.2)} \mathrm{for} 1 \mathrm{~h}$. After fixation, the slices were washed in buffer, dehydrated with ethanol, washed in propylene oxide and embedded in epoxylite resin. Thin sections were cut with glass knives and examined with an AEI 6B electron microscope.

\section{Results}

\section{Long-term ovarian function}

Removal of one ovary from young virgin mice did not disturb the normal rhythm of cyclic activity, although it led to a restoration of the normal total number of ova shed at the next oestrus. This compensatory response was not reduced with increasing age in either the virgin mice up to 30 weeks of age or in the breeding colony after as many as 7 pregnancies (Tables 2 and 3). Multiparous animals of the CBA/Ca strain in particular tended to have more $\mathrm{CL}$ and, therefore, presumably a higher ovulation number than primigravidae of the same age; young primigravidae had significantly fewer CL than either of these elderly groups $(P<0.05)$.

\section{Breeding experiments}

The size of the first litter in unilaterally ovariectomized CFLP mice was reduced significantly compared to intact controls (Table 1), although the difference in $\mathrm{CBA} / \mathrm{Ca}$ animals only reached an acceptable level of statistical significance $(P<0.02)$ in a larger series of animals $(\mathrm{N}=67)$. The total number of live fetuses and placental scars in young primigravid CBA/Ca mice was similar in operated animals and controls on Day 19, although there was a slight, but significant, reduction in fetal wet weight and protein weight in animals accommodating the entire litter in one horn $(P<0 \cdot 05)$. Adjacent placentae were occasionally found to be attached to each other. These so-called close pairs were more common in the overcrowded horns of animals with a single ovary $(P<0.025)$.

Table 1. Life-time breeding performance of intact (controls) and unilaterally ovariectomized (Ovx) $\mathrm{CBA} / \mathrm{Ca}$ and CFLP mice

\begin{tabular}{|c|c|c|c|c|c|c|}
\hline Strain & Group & $\begin{array}{l}\text { No. of } \\
\text { mice }\end{array}$ & $\begin{array}{l}\text { Live births } \\
\text { of first } \\
\text { litter }\end{array}$ & $\begin{array}{l}\text { No. of } \\
\text { litters }\end{array}$ & $\begin{array}{l}\text { Live births } \\
\text { /female }\end{array}$ & $\begin{array}{c}\text { Age at last parturition } \\
\text { (days) }\end{array}$ \\
\hline $\mathrm{CBA} / \mathrm{Ca}$ & $\begin{array}{l}\text { Intact } \\
\text { Ovx }\end{array}$ & $\begin{array}{l}14 \\
14\end{array}$ & $\begin{array}{l}5.4 \pm 0.7 \\
4.2 \pm 0.4\end{array}$ & $\begin{array}{l}4.9 \pm 0.3 \\
3.9 \pm 0.4^{*}\end{array}$ & $\begin{array}{l}28.1 \pm 1.6 \\
18.4 \pm 1.7 \dagger\end{array}$ & $\begin{array}{l}197 \pm 10(149-272) \\
191 \pm 8 \quad(141-238)\end{array}$ \\
\hline CFLP & $\begin{array}{l}\text { Intact } \\
\text { Ovx }\end{array}$ & $\begin{array}{l}24 \\
24\end{array}$ & $\begin{array}{l}12.5 \pm 0.4 \\
9.3 \pm 0.7 \dagger\end{array}$ & $\begin{array}{l}8 \cdot 1 \pm 0.5 \\
5.4 \pm 0.4 \dagger\end{array}$ & $\begin{array}{l}95 \cdot 9 \pm 6 \cdot 6 \\
48 \cdot 3 \pm 4 \cdot 4 \dagger\end{array}$ & $\begin{array}{l}271 \pm 13(164-427) \\
226 \pm 12^{*}(144-339)\end{array}$ \\
\hline
\end{tabular}

Values are mean \pm s.e.m. with range in parentheses.

$* P<0.05$ compared with controls.

$+P<0.001$ compared with controls. 
Fewer litters were produced during the course of the breeding life-span in animals with one ovary than in their controls, the reduced fertility of the CFLP mice also being associated with an earlier cessation of breeding activity (Table 1). Autopsy results showed that conception without progression to full term had occurred after the birth of the last litter in the experimental and control animals.

The contrasting patterns of breeding activity in the two groups of animals are shown by comparison of the average productivity of the functioning uterine horns in successive litters (Text-fig. 1). The number of live young/horn in intact animals increased initially and then gradually declined to a low value whereas unilaterally ovariectomized mice maintained an increased number of fetuses/horn for several litters and then abruptly stopped breeding. The high value at litter number 8 in intact $\mathrm{CBA} / \mathrm{Ca}$ mice was due to a single exceptional animal. The lifetime production of live young/horn was not very different in the two groups but, on a whole animal basis, the total number produced was reduced in unilaterally ovariectomized $\mathrm{CBA} / \mathrm{Ca}$ and CFLP mice to 65 and 50\%, respectively, of control values. The levels of maternal morbidity and mortality in the experimental and control animals were equally low, despite the unusually intensive breeding activity.

Delayed breeding affected the size of and likelihood of having a litter. Only 2 out of 13 old primigravid CBA/Ca mice produced litters, and these contained only 1 and 3 live offspring.

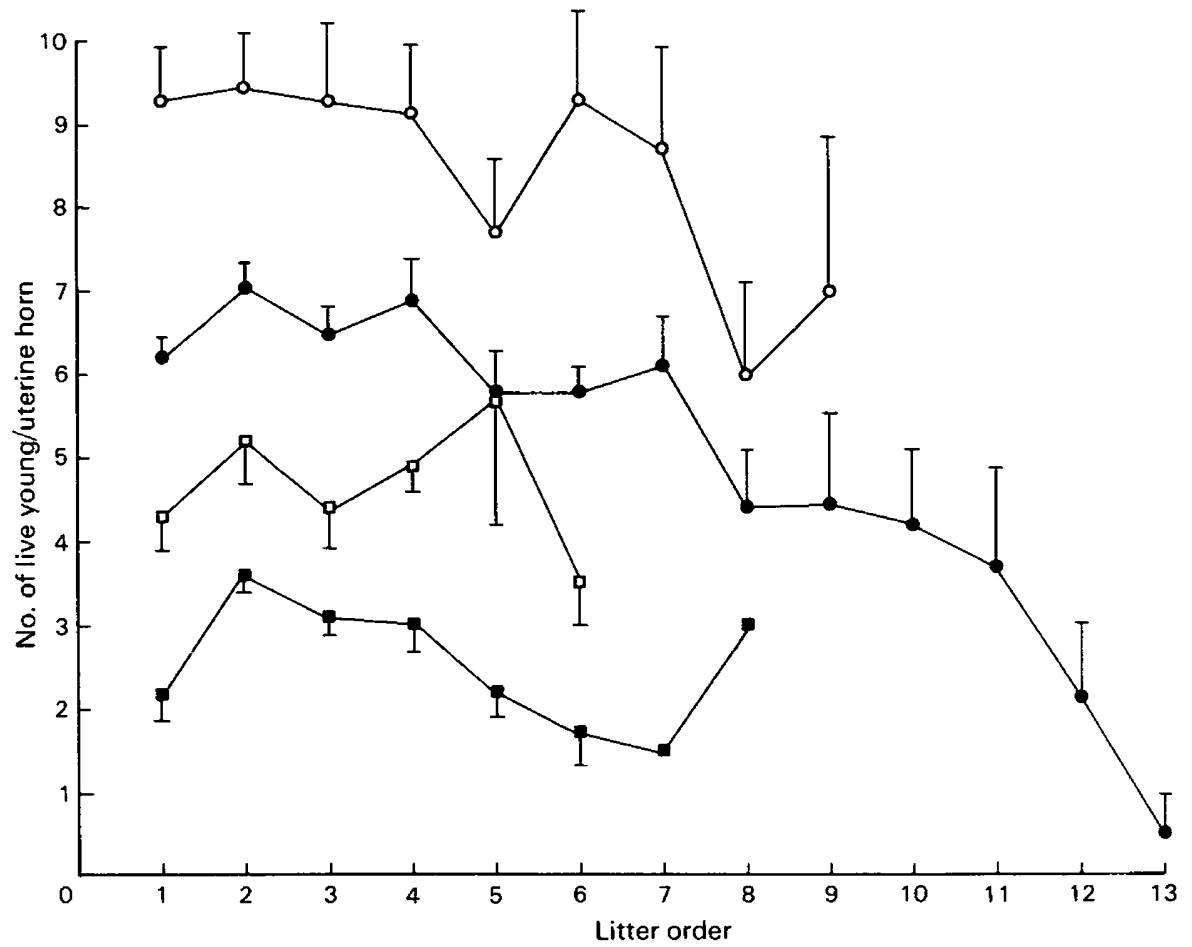

Text-fig. 1. Mean ( \pm s.e.m.) numbers of living young produced per uterine horn during the breeding life-span of mice. $\mathbf{\square}$, Intact $\mathrm{CBA} / \mathrm{Ca}(\mathrm{N}=14) ; \square$, unilaterally ovariectomized $\mathrm{CBA} / \mathrm{Ca}$ $(\mathrm{N}=14) ;$, intact CFLP $(\mathrm{N}=24) ; O$, unilaterally ovariectomized CFLP $(\mathrm{N}=24)$.

\section{Embryo transfer}

Both uterine horns in young primigravid mice had the same potential for supporting implantation and development of embryos transferred within 4 weeks of unilateral ovariectomy (Table 3). The results were essentially the same when transfer was delayed 12-18 weeks after 
Table 2. Survival of embryos transferred bilaterally to $\mathrm{CBA} / \mathrm{Ca}$ mice differing in age, parity and presence of one or both ovaries during reproductive life

\begin{tabular}{llcccr}
\hline \multicolumn{1}{c}{ Group } & $\begin{array}{c}\text { Side of } \\
\text { transfer }\end{array}$ & $\begin{array}{c}\text { No. of } \\
\text { recipients }\end{array}$ & $\begin{array}{c}\text { No. of embryos } \\
\text { transferred (Day 4) }\end{array}$ & $\begin{array}{c}\text { Survival on } \\
\text { Day 19 (\%) }\end{array}$ & $\begin{array}{c}\text { Mean } \pm \text { s.e.m. } \\
\text { no. of CL }\end{array}$ \\
\hline Young primigravidae & Both horns & 10 & 82 & $50(61)$ & $7.6 \pm 0.5$ \\
Old primigravidae & Both horns & 7 & 66 & $22(33)$ & $9.7 \pm 0.8$ \\
Old multigravidae & Both horns & 8 & 75 & $22(29)$ & $11.6 \pm 0.5$ \\
Old multigravidae & Intact side & 9 & 44 & $13(30)$ & \\
unilaterally & Ovx side & 9 & 42 & $7(17)$ & \\
ovariectomized & Both sides & 9 & 86 & $20(23)$ & $11.3 \pm 0.5$ \\
\hline
\end{tabular}

Embryo survival was significantly affected by age of recipient $(P<0.01)$ but not by other variables.

Table 3. Survival of embryos transferred unilaterally to CBA/Ca and CFLP mice differing in age, parity and presence of one or both ovaries during reproductive life

\begin{tabular}{|c|c|c|c|c|c|}
\hline Strain & Group (side of ovum transfer) & $\begin{array}{l}\text { No. of } \\
\text { recipients }\end{array}$ & $\begin{array}{l}\text { No. of } \\
\text { embryos } \\
\text { transferred } \\
\text { (Day 4) }\end{array}$ & $\begin{array}{l}\text { Survival on } \\
\text { Day } 19 \\
(\%)\end{array}$ & $\begin{array}{c}\text { Mean } \pm \text { s.e.m. } \\
\text { no. of CL }\end{array}$ \\
\hline \multirow{7}{*}{$\mathrm{CBA} / \mathrm{Ca}$} & Young primigravidae $(R)$ & 3 & 19 & $10(52)$ & $9.7 \pm 0.3$ \\
\hline & Young primigravidae uni-ovx (intact side) & 6 & 39 & $21(54)$ & \\
\hline & Young primigravidae uni-ovx (ovx side) & 8 & 48 & $26(54)$ & $9.1 \pm 0.4$ \\
\hline & Old primigravidae $(\mathrm{R})$ & 5 & 43 & $0(0)$ & Regressed \\
\hline & Old multigravidae (R) & 4 & 46 & $22(48)$ & $11 \cdot 3 \pm 0.5$ \\
\hline & Old multigravidae uni-ovx (intact side) & 9 & 97 & $23(24)$ & \multirow{2}{*}{$10 \cdot 3 \pm 0.4$} \\
\hline & Old multigravidae uni-ovx (ovx side) & 7 & 72 & $1(1)$ & \\
\hline \multirow[t]{5}{*}{ CFLP } & Young primigravidae (R) & 13 & 117 & $75(64)$ & $13 \cdot 5 \pm 0 \cdot 8$ \\
\hline & Old primigravidae $(\mathrm{R})$ & 3 & 37 & $12(32)$ & $14 \cdot 0 \pm 3 \cdot 0$ \\
\hline & Old multigravidae (R) & 5 & 54 & $26(48)$ & $15 \cdot 8 \pm 1 \cdot 7$ \\
\hline & Old multigravidae uni-ovx (intact side) & 3 & 39 & $15(38)$ & \multirow{2}{*}{$13.5 \pm 1.5$} \\
\hline & Old multigravidae uni-ovx (ovx side) & 3 & 39 & $10(26)\}$ & \\
\hline
\end{tabular}

$\mathrm{R}=$ side chosen at random.

Embryo survival was significantly affected by age and parity of recipient (see text for details).

surgery: $25 / 63$ fetuses survived on the ovariectomized side compared to $41 / 96$ on the control side. The survival of embryos in young animals with one ovary did not differ significantly from controls. Examination of the raw data did not reveal any evidence of differential fetal survival in the right and left horns or of internal migration when embryos had been introduced to only one side of the uterus ( $\mathrm{N}=94$ unilateral pregnancies).

Fewer transferred embryos survived to term in the uteri of old than in young animals (Tables 2 and $3, P<0.01$ by $\chi^{2}$ ). The gestational history of individual horns did not significantly affect the success of pregnancy established by bilateral transfer of embryos (Table 2). In these experiments only about half as many embryos survived in the contralateral (and therefore previously barren) horns of multiparae with one ovary as in the ipsilateral (and multigravid) horns of the same animals. This trend was statistically significant in subsequent experiments in which the entire set of embryos was transferred to a single horn (Table 3). All embryos died in the aged intact primigravidae and there was only one survivor in the previously barren horn of unilaterally ovariectomized multigravid $\mathrm{CBA} / \mathrm{Ca}$ mice. This survival proportion was significantly lower than that of the multigravid horn of one-ovary mice $(P<0.001)$ which, in turn, was significantly lower than that for the multigravid horn of intact animals $(P<0.01)$. Similar trends were found after transfers to a smaller but comparable series of CFLP mice. Embryo survival was lower in old animals of this strain $(P<0.01)$. The uterine horns of intact multiparous mice 
were more acceptable sites for implantation and development than were the previously barren horns of old multiparous mice $(P<0.05)$.

Signs of embryonic resorption were common in multigravidae but absent from primigravidae of the same age. The full-term fetuses of old animals were similar in weight to those of young individuals with the same litter size. The fetal :placental weight ratios were also similar in the two groups.

\section{Decidual cell reaction}

The number of stimuli applied to the uteri of young mice corresponded closely to the number of deciduomata found at autopsy. The response of old uteri to similar treatment was severely impaired (Table 4). Weight changes of right and left horns did not differ significantly. Statistical comparisons of weight changes between individual groups were made by using values derived from the difference between the horn weight and the mean of the pooled control values. The procedure overcame the problem of non-equivalence of the two horns of previously unilaterally pregnant mice. The decidual responses had large variances and no significant differences were found when old uteri with different histories were compared. Exceptionally, the response of the barren horn of unilaterally ovariectomized CFLP mice was less than that of the multiparous horn of similar animals $(P<0.05)$.

Table 4. The response of ovariectomized, hormone-primed mice to decidualizing stimuli in relation to age, parity and presence of one or both ovaries during reproductive life

\begin{tabular}{|c|c|c|c|c|c|c|c|}
\hline \multirow[b]{2}{*}{ Strain } & & & \multirow{2}{*}{$\begin{array}{c}\text { Animals with } \\
1 \text { or more } \\
\text { deciduomata/ } \\
\text { total } \\
\text { animals }\end{array}$} & \multirow{2}{*}{$\begin{array}{c}\text { No. of } \\
\text { deciduomata }\end{array}$} & \multicolumn{3}{|c|}{ Wt of uterine horn (mg) } \\
\hline & \multicolumn{2}{|c|}{ Group } & & & $\begin{array}{l}\text { Stimulated } \\
\text { side }\end{array}$ & $\begin{array}{l}\text { Unstimulated } \\
\text { side }\end{array}$ & $\begin{array}{c}\% \\
\text { change }\end{array}$ \\
\hline \multirow[t]{5}{*}{ CFLP } & Young nulliparae & & $7 / 7$ & $2.9 \pm 0.3$ & $73 \pm 11$ & $36 \pm 3$ & $102 \pm 31$ \\
\hline & Old nulliparae & & $2 / 8^{*}$ & $2.0 \pm 1.0$ & $67 \pm 13$ & & $19 \pm 24$ \\
\hline & Old multiparae & & $2 / 6^{*}$ & $2.0 \pm 0.0$ & $84 \pm 10$ & $72 \pm 10$ & $17 \pm 14$ \\
\hline & Old multiparous, & $\left\{\begin{array}{c}\text { Intact side } \\
\text { stimulated }\end{array}\right.$ & $3 / 7$ & $1.7 \pm 0.7$ & $88 \pm 12$ & $67 \pm 5$ & $31 \pm 17$ \\
\hline & $\begin{array}{l}\text { unilaterally } \\
\text { ovariectomized }\end{array}$ & $\left\{\begin{array}{l}\text { Ovx side } \\
\text { stimulated }\end{array}\right.$ & $4 / 7$ & $2.0 \pm 0.6$ & $60 \pm 11$ & $79 \pm 18$ & $-25 \pm 14 \S$ \\
\hline $\mathrm{CBA} / \mathrm{Ca}$ & $\begin{array}{l}\text { Young nulliparae } \\
\text { Old multiparae }\end{array}$ & & $\begin{array}{r}10 / 10^{\dagger} \\
3 / 10^{\dagger}\end{array}$ & $\begin{array}{l}2.9 \pm 0.1 \\
1.7 \pm 0.3\end{array}$ & $\begin{array}{l}53 \pm 7 \\
61 \pm 7\end{array}$ & $\begin{array}{l}25 \pm 1 \\
45 \pm 3\end{array}$ & $\begin{array}{r}115 \pm 27 \ddagger \\
35 \pm 15 \ddagger\end{array}$ \\
\hline
\end{tabular}

Values are mean \pm s.e.m.

$* P<0.05$ compared to young animals.

$\dagger P<0.005$.

$\ddagger P<0.02$.

$\S \mathrm{F}_{4,30}=4.45(P<0.01)$; each old group was significantly smaller than the young control $(P<0.05)$.

\section{Microscopical studies}

Parous uterine horns contained large numbers of pigment cells which accounted for their yellow-brown discoloration. Pigment cells were sparse in nulliparous horns $(<10$ per transverse section), even when the other horn in the same animal was multiparous and, consequently, heavily pigmented. The pigment appeared shortly after parturition in primiparae. Much of this material persisted in the uterine wall, the characteristic difference in pigment density between the horns of multiparous unilaterally ovariectomized mice lasting at least 58 weeks after the last litter. Most of the pigment cells were found in the muscle layers and were often present as focal accumulations on the mesometrial side.

The pigment cells were presumed to be macrophages on the basis of their fine structural appearance and presence of hydrolytic enzyme activity. The pigment granules exhibited golden- 
yellow autofluorescence (Pl. 1, Fig. 1) and other histochemical characteristics of lipofuscin. They also contained iron (PI. 1, Fig. 2). Most macrophages seen by electron microscopy contained a single nucleus and many polymorphic cytoplasmic granules, some of which resembled lipofuscin granules (Pl. 1, Fig. 3). They were notably deficient in mitochondria, Golgi apparatus and endoplasmic reticulum and, consistent with these observations, there was no clear morphological evidence of continuing phagocytosis in the majority of cells.

Mast cells were more abundant in the myometrium than in the endometrium but both tissues tended to accumulate them in old age (Table 5). The effect of age on mast cell density in the myometrium was highly significant $(P<0.01)$; gestational history and unilateral ovariectomy had no affect on their density.

Table 5. Mast cell density (mean \pm s.e.m.) in uterine horns of $\mathrm{CBA} / \mathrm{Ca}$ mice differing in age, reproductive history and presence of one or both ovaries

\begin{tabular}{lcccc}
\hline \multicolumn{1}{c}{ Group } & & \multicolumn{2}{c}{ No. of mast cells $/ \mathrm{mm}^{2}$} \\
\cline { 4 - 5 } & & $\begin{array}{c}\text { No. of } \\
\text { mice }\end{array}$ & Myometrium & Endometrium \\
\hline Young nulliparae & 5 & $51.6 \pm 8.6$ & $0.4 \pm 0.4$ \\
Old multiparae & 5 & $184.1 \pm 23.9$ & $3.6 \pm 1.7$ \\
Old unilaterally ovariectomized multiparae & Multiparous side & 5 & $152.4 \pm 18.8$ & $2.4 \pm 1.2$ \\
& Barren side & 5 & $140.9 \pm 21.7$ & $2.0 \pm 1.3$ \\
\hline
\end{tabular}

Myometrial cell density varied significantly between groups $\left(\mathrm{F}_{3,16}=8.78, P<0.01\right)$, young uteri having lower values than other types $(P<0.01)$.

\section{Discussion}

In contrast to the present results, there is some evidence that unilateral ovariectomy in mice accelerates senescence of the remaining ovary. Thung (1961) found that the frequency of normal oestrous cycles was lower in animals with one ovary than in intact controls. This effect did not, however, appear until more than 7 months after surgery of animals that were already old. It was probably not a primary ovarian effect because the rate of depletion of the follicle reserve is apparently unchanged after unilateral ovariectomy (Jones \& Krohn, 1960). There is also the possibility that the quality of ova shed is further reduced in ageing mice by removal of an ovary (Henderson \& Edwards, 1968). The finding that ovum survival is dependent on the age and breeding history of the recipient rather than the donor does not refute the hypothesis but minimizes the significance of ovum defects in intrauterine death in ageing mice (Talbert \& Krohn, 1966; Gosden, 1974). The function of the CL appears to be maintained in old age judging from measurements of circulating progesterone during pregnancy (Parkening, Lau, Saksena \& Chang, 1978; Gosden \& Fowler, 1979) and the normal histological appearance of the CL (Biggers et al., 1962a). It is therefore highly improbable that ovarian dysfunction is primarily responsible for pregnancy failure in ageing animals with one ovary.

\section{PLATE 1}

Fig. 1. Presumptive macrophages in the uterine wall of a multiparous mouse showing intensely autofluorescent lipofuscin granules. Ultraviolet fluorescence/dark-ground illumination, $\times \mathbf{4 3 0}$.

Fig. 2. Transverse section of uterine horn of a multiparous mouse approximately 3 months post partum. Numerous iron-laden macrophages are present, especially between the muscle coats on the mesometrial side. $\mathrm{L}=$ lumen. Perl's stain and neutral red, $\times 47$.

Fig. 3. Electron micrograph of a uterine macrophage from a multiparous mouse approximately 3 months post partum. The cell is replete with dense granular material ( $\mathrm{L}=$ lipofuscin granule) and multivesicular bodies (M) but is deficient in mitochondria and other membranous cytoplasmic structures. Glutaraldehyde and osmium, $\times 6350$. 
PLATE 1
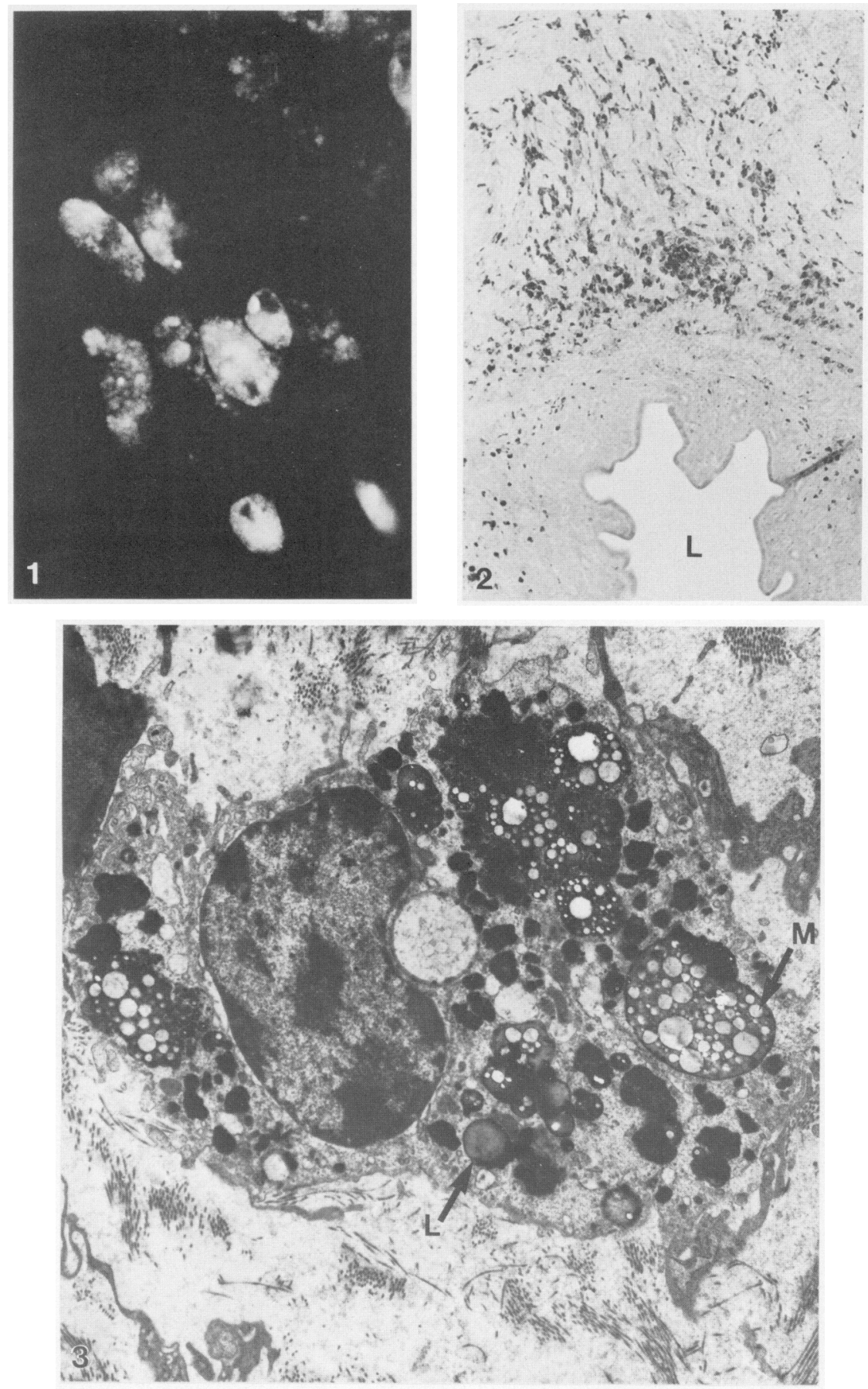

(Facing p. 484) 
According to Biggers et al. (1962b), the reduced breeding potential of one-ovary mice is due to localized uterine ageing resulting from repeated feto-placental overloading of the functioning horn. The hypothesis was supported mainly by indirect evidence and assumed that compensatory ovulation is maintained with otherwise normal ovarian function and that internal migration of ova is rare. The present study corroborates both of these assumptions and provides direct evidence of premature uterine failure. The same explanation may apply to the results of comparable studies in mice, rats and rabbits, but the different effects of unilateral ovariectomy on the number of litters and age at the last parturition may be variations of a common factor, e.g. prenatal mortality (Adams, 1970). The major difference between the breeding patterns of intact and one-ovary mice is the earlier and more abrupt failure of the latter to maintain the complement of ova. During their lifetime, intact and one-ovary animals produce a similar number of living young per uterine horn which seems to imply that each horn is endowed with a 'quota' of implantations which would be spent during a lifetime by a relatively normal level of gestational activity.

The results of unilateral transfer of embryos provide direct proof that the uterus is less able to maintain implantations after exposure to conditions of overioading. The failure to show such an effect by bilateral transfer experiments may have been due to the younger age of the animals used or to the smaller numbers of ova injected per horn, and, hence, decreased challenge to uterine function. Density-dependent death of embryos might result from a lack of suitable implantation sites or from a decreased ability of the uterus to maintain a given feto-placental metabolic load. Reduction of the feto-placental load is beneficial for reproduction in old animals if it affords an opportunity for preferential elimination of abnormal fetuses or if it makes scarce resources available so that surviving fetuses can grow normally.

Delayed breeding did not preserve the uterus from the effects of ageing. Embryonic survival in previously barren horns of unilaterally ovariectomized multiparae was even less successful than in the opposite parous horn. Other studies have shown a detrimental effect of delayed breeding in rodents, although the embryonic contribution to infertility was not known (Asdell, Bogart \& Sperling, 1941; Nishimura \& Shikata, 1960). However, not all studies have shown a difference between the litter sizes of elderly primigravidae and multigravidae (Finn, 1963), although this may be due to age differences at the test breeding between the various studies. Perhaps the uterus requires stimulation by the physiological changes of pregnancy during a 'critical period' of mature life to optimize the long-term breeding potential. The higher rates of ovulation in multiparous than in primiparous CBA/Ca mice may be an example of a comparable process affecting the control of the ovaries. The ovulation effect might also be explained by differences in body weight (Kennedy \& Kennedy, 1972).

There are many possible explanations for the reduced breeding potential. The differences in function of barren and multiparous horns of unilaterally ovariectomized mice suggest that local uterine factors are responsible for embryonic mortality since the systemic conditions were similar. Although different factors may be responsible for the detrimental effects of prolonged nulliparity and repeated overloading, the present results do not provide insight. It is possible that the different functional capacities of ageing uteri are due to a common factor, such as vascular or collagen ageing, which has different rate constants according to the local gestational history.

Embryonic death in aged animals has been attributed to vascular or collagen ageing because uterine blood flow during pregnancy (Larson \& Foote, 1972) and collagen content and quality (Schaub, 1964/65) vary with age. However, direct proof for the involvement of these factors is still lacking. Collagen has sometimes been dismissed as a possible contributory factor to the decline of uterine function in unilaterally ovariectomized multiparae because both horns of these animals have a similar amount of collagen (Finn, Fitch \& Harkness, 1963). The collagen hypothesis should now be reappraised because the nulliparous horn is evidently not preserved from early senescence, as has been assumed.

It is known that the decidual cell reaction is reduced in aged mice (Finn, 1966; Shapiro \& 
Talbert, 1974; Holinka \& Finch, 1977), but the effect of breeding history has not been previously reported. The smaller weight changes resulting from decidualizing stimuli in nulliparous horns of one-ovary mice compared to other groups was interesting in view of the particularly low gestational potential of these horns. However, firm conclusions about the functional significance of the reduction in decidual cell reaction in ageing uteri cannot be drawn from this kind of data because of considerable variability in response.

The effect of the fetal crowding in animals with one ovary can account for the greater numbers of placental 'fusions' and, hence, perhaps for the smaller litter size of young primigravidae than would be expected with compensatory ovulation. However, the independence of placental fusions from age and parity, and the early embryonic death in elderly primigravidae implies that fetal crowding cannot explain the long-term breeding data.

The relation of uterine morphology to functional potential was studied when dense pigmentation was found in the uterine horns of aged animals. Microscopy revealed marked changes in the populations of macrophages and mast cells with parity and age, respectively. The haemosiderin and lipofuscin pigments accumulating in macrophages were probably end-products of intracellular digestion of material taken up by cells involved in 'clearing-up' operations and remodelling of the uterus after parturition (Parakkal, 1969). Pregnancy can evidently be successful in the presence of uterine pigmentation because pigment cells accumulate progressively with parity whereas breeding performance does not decline until after several pregnancies. It is possible that implantation or placental function might be impaired in the heavily scarred uteri of multiparae. In less heavily pigmented uteri the effect of the persistent scar tissue would depend on whether ova preferentially implant between unfavourable sites, as may occur in the hamster (Orsini, 1962).

There is tentative evidence to show that the mechanism of implantation in rats depends on the presence of mast cells (Ferrando \& Nalbandov, 1968). However, there is no reason to think that the increased density of mast cells in aged uteri is other than harmless or beneficial. It is, of course, still possible that the function of these individual cells is deficient. The age difference in mast cell density may be due to differences in hormonal environment (e.g. oestrogen) or it may be part of a generalized change in density throughout the body because the numbers of peritoneal mast cells have been found to increase with age (Ennërback \& Mellblom, 1978).

Further experiments are required to show whether a causal relationship exists between any of the uterine changes described here and decreased organ function. The present results do, however, lead to the conclusion that breeding history affects subsequent breeding potential and a relatively normal level of gestational function must be optimal for long-term breeding performance.

I thank Kay Grant and Noel Brown for excellent technical assistance and Davina McCrink for help with the manuscript. Part of these studies was generously supported by the Medical Research Council and the Ford Foundation.

\section{References}

Adams, C.E. (1970) Ageing and reproduction in the female mammal with particular reference to the rabbit. J. Reprod. Fert., Suppl. 12, 1-16.

Asdell, S.A., Bogart, R. \& Sperling, G. (1941) The influence of age and rate of breeding upon the ability of the female rat to reproduce and raise young. Mem. Cornell Univ. agric. Exp. Stn, 238, 1-26.

Biggers, J.D., Finn, C.A. \& McLaren, A. (1962a) Longterm reproductive performance of female mice. I.
Effect of removing one ovary. J. Reprod. Fert. 3, 303-312.

Biggers, J.D., Finn, C.A., McLaren, A. \& Woolf, B. (1962b) Long-term reproductive performance of female mice. II. Variation of litter size with parity. $J$. Reprod. Fert. 3, 313-330.

Blaha, G.C. (1964) Reproductive senescence in the female golden hamster. Anat. Rec. 150, 405-411.

Ennërback, L. \& Mellblom, L. (1978) 5-hydroxy- 
tryptamine content of mast cells, mast cell numbers and body growth. Expl. Cell Res. 112, 103-109.

Ferrando, G. \& Nalbandov, A.V. (1968) Relative importance of histamine and estrogen on implantation in rats. Endocrinology 83, 933-937.

Finn, C.A. (1963) Reproductive capacity and litter size in mice. Effect of age and environment. $J$. Reprod. Fert. 6, 205-214.

Finn, C.A. (1966) The initiation of the decidual cell reaction in the uterus of the aged mouse. J. Reprod. Fert. 11, 423-428.

Finn, C.A., Fiteh, S.M. \& Harkness, R.D. (1963) Collagen content of barren and previously pregnant uterine horns in old mice. J. Reprod. Fert. 6, 405407.

Gosden, R.G. (1974) Survival of transferred C57BL mouse embryos: effects of age of donor and recipient. Fert. Steril 25, 348-351.

Gosden, R.G. \& Fowler, R.E. (1979) Corpus luteum function in ageing inbred mice. Experientia 35, 128130.

Henderson, S.A. \& Edwards, R.G. (1968) Chiasma frequency and maternal age in mammals. Nature, Lond. 218, 22-28.

Holinka, C.F. \& Finch, C.E. (1977) Age-related changes in the decidual cell response of the $\mathrm{C} 57 \mathrm{BL} / 6 \mathrm{~J}$ mouse uterus. Biol. Reprod. 16, 385-393.

Jones, E.C. \& Krohn, P.L. (1960) The effect of unilateral ovariectomy on the reproductive lifespan of mice. $J$. Endocr. 20, 129-134.

Kennedy, T.G. \& Kennedy, J.P. (1972) Effects of age and parity on reproduction in young female mice. $J$. Reprod. Fert. 28, 77-84.

Larson, L.L. \& Foote, R.H. (1972) Uterine blood flow in young and aged rabbits. Proc. Soc. exp. Biol. Med. 141, 67-69.

Lowry, O.H., Rosebrough, J.J., Farr, A.L. \& Randall, R.J. (1951) Protein measurement with the Folin phenol reagent. J. biol. Chem. 193, 265-275.
McLaren, A. (1966) Regulation of ovulation rate after removal of one ovary in mice. Proc. $R$. Soc. $B$ 166, $316-340$.

Nishimura, H. \& Shikata, A. (1960) High embryonic mortality of the mouse fetuses from the elderly primigravid mothers. Okijimas Folia anat. jap. 36, $151-154$.

Orsini, M.W. (1962) Technique of preparation, study and photography of benzyl-benzoate cleared material for embryological studies. $J$. Reprod. Fert. 3, 283-287.

Parakkal, P.F. (1969) Involvement of macrophages in collagen resorption. J. Cell Biol. 41, 345-354.

Parkening, T.A., Lau, I.F., Saksena, S.K. \& Chang, M.C. (1978) Circulating plasma levels of pregnenolone, progesterone, estrogen, luteinizing hormone, and follicle stimulating hormone in young and aged C57BL/6 mice during various stages of pregnancy. J. Geront. 33, 191-196.

Pearse, A.G.E. (1968) Histochemistry, Theoretical and Applied, 3rd edn, Vol. I. Churchill, London.

Pearse, A.G.E. (1972) Histochemistry, Theoretical and Applied, 3rd edn, Vol. II. Churchill, London.

Schaub, M.C. (1964/65) Changes of collagen in the ageing and in the pregnant uterus of white rats. Gerontologia 10, 137-145.

Shapiro, M. \& Talbert, G.B. (1974) The effect of maternal age on decidualization in the mouse. $J$. Geront. 29, 145-148.

Talbert, G.B. \& Krohn, P.L. (1966) Effect of maternal age on viability of ova and uterine support of pregnancy in mice. J. Reprod. Fert. 11, 399-406.

Thung, P.J. (1961) Ageing changes in the ovary. In Structural Aspects of Ageing, pp. 109-142. Ed. G.H. Bourne. Pitman Medical, London.

Whittingham, D.G. (1971) Survival of mouse embryos after freezing and thawing. Nature, Lond. 233, 125126.

Received 16 March 1979 